\title{
Fabrication of densified wood via synergy of chemical pretreatment, hot-pressing and post mechanical fixation
}

\author{
Jiangtao Shi ${ }^{1,2^{*}} \mathbb{D}$, Junyi Peng ${ }^{1}$, Qiongtao Huang ${ }^{2}$, Liping Cai ${ }^{1,3}$ and Sheldon Q. Shi ${ }^{3}$
}

\begin{abstract}
Wood densification can improve the strength of low density wood species and extend wood product applications. To enhance the wood compressive quality, chemical pretreatments for pristine wood have widely been used. Densified Abies wood was fabricated by combining $\mathrm{NaOH} / \mathrm{Na}_{2} \mathrm{SO}_{3}$ solution treatment, hot-pressing and post mechanical fixation. The appearance, color, chemical composition, and physiology and mechanical properties before and after the densification treatment were examined by the colorimeter, FTIR and mechanical testing machine, respectively. Surface color of Abies wood was changed obviously after the densification. The values of brightness $L^{*}$ and $b^{*}$ decreased but the value of $a^{*}$ showed a slight increase in the densified wood. FTIR results confirmed that the color changes can be explained by the degradation of hemicellulose and lignin in wood cell walls and migration of extractives during the densification process. Sufficient removal of wood polymers resulted in the average compression ratio of about $80 \%$ in the radial direction of the natural wood. The density of densified wood increased with the wood thickness up to $1.227 \mathrm{~g} \mathrm{~cm}^{-1}$, accounting for a $169 \%$ increase compared to that of the pristine wood. Modulus of rupture (MOR) and modulus of elasticity (MOE) in the thickness direction of densified wood also markedly enhanced. Degradation of polymers in wood cell walls also was reconfirmed by the difference of fracture interface. All the results suggested that the densified softwood can be easily fabricated using the proposed method and the new densified softwood can be appropriately used as interior decoration materials.
\end{abstract}

Keywords: Densification, Abies wood, Decorative panel, Hot-pressing, $\mathrm{NaOH} / \mathrm{Na}_{2} \mathrm{SO}_{3}$ pretreatment

\section{Introduction}

Wood densification is one of the effective techniques for improving the strength of low density wood species, which can effectively extend wood product application due to the enhanced density of surfaces or entirety of wood. As early as 1930s, the densified wood was used replacing metal materials in military aircraft in USA and Germany. In recent decades, many approaches were completed for manufacturing densified wood, such as mechanical thermal pressing [1], viscoelastic thermal compression (VTC) [2]. Whatever the compression

\footnotetext{
*Correspondence: shijt@njfu.edu.cn

${ }^{1}$ College of Materials Science and Engineering, Nanjing Forestry

University, Nanjing 210037, China

Full list of author information is available at the end of the article
}

methods, softening of wood material before mechanical pressing is required. The process of softening is known as a pretreatment and combined with following mechanical pressing, achieving better compressing result. The thermo-mechanical densification [3-5], thermal-hydromechanical [6-8], hygro-mechanical steam treatment $[9,10]$, mechanical-microwave treatment [11], and highpressure treatment $[12,13]$ were developed to manufacture densified wood, in which the thermal-hydro is the most common and simplest pretreatment method currently. The cell walls of wood would be swelled by water although it cannot penetrate into crystalline region of cellulose. Then, the glass-transition temperature of amorphous polymers (hemicellulose and lignin) decreases under the hydrothermal condition. As a result, the pretreated wood allows low compressive force while without
SpringerOpen

(c) The Author(s) 2020. This article is licensed under a Creative Commons Attribution 4.0 International License, which permits use, sharing, adaptation, distribution and reproduction in any medium or format, as long as you give appropriate credit to the original author(s) and the source, provide a link to the Creative Commons licence, and indicate if changes were made. The images or other third party material in this article are included in the article's Creative Commons licence, unless indicated otherwise in a credit line to the material. If material is not included in the article's Creative Commons licence and your intended use is not permitted by statutory regulation or exceeds the permitted use, you will need to obtain permission directly from the copyright holder. To view a copy of this licence, visit http://creativeco mmons.org/licenses/by/4.0/. 
breaking wood cell walls during the next hot-pressing. However, partly elastic deformation is reversible in this densified wood, especially in earlywood. Therefore, the recovery of deformation under humidity condition is an inevitable problem. Previous reports stated that water absorption expansion ratio in the compression direction reached up to $50 \%$ if the deformation in densified wood was not fixed [14]. Some methods, such as high-temperature steam, resin impregnation, and high-frequency microwave heating, are mostly used for deformation fixation of densified wood in the wood industry.

However, combination of chemical pretreatment and mechanical compression maybe an effective method to solve the recovery in densified wood [15]. Wood polymers always degraded and extracted in the chemical pretreatment. Alkaline solution, such as sodium hydrate or potassium hydroxide (10-20\%), is the mostly chemical pretreatment method used for the wood densification manufacturing. On the other hand, alkaline solution is normally used in the pulping industry. Under the alkaline condition, cellulose, hemicellulose and lignin all would be swelled or hydrolyzed at different levels. Wood disintegration in cells or cell walls facilitates the maximum compression in hot press. Ammonia is another reagent for pretreatment in the manufacturing of densified wood because it has a relatively high affinity to the polymers in wood cell walls. Although ammonia treatment shows no obvious effect on the content of wood polymers, it can easily access crystal region of cellulose and disrupt the lignin-carbohydrate complex. Moreover, the plasticizing effect of the ammonia treatment is temporary and the deformed wood would be returning back to its initial form and the strong pungent smell after the ammonia treatment limits its industrial application $[16,17]$. Later, Song et al. manufactured the highstrength densified wood by coalescent method which combined $\mathrm{NaOH} / \mathrm{Na}_{2} \mathrm{SO}_{3}$ solution pretreatment and hot press at $100{ }^{\circ} \mathrm{C}$, exhibiting high specific tensile strength of $422.2 \mathrm{MPa} \mathrm{cm} \mathrm{g}^{3}$, which is higher than some metals [18]. In recent years, $\mathrm{NaOH} / \mathrm{Na}_{2} \mathrm{SO}_{3}$ solution system was widely used to degrade hemicellulose and lignin in wood cell walls for preparing transparent wood composites [19], super flexible wood [20] or other functional wood materials [21].

Widely planted in North America and Nordic region, Abies wood is one of the vital softwood species used in residential buildings and other construction materials. Compared to hardwood, softwood commonly consists of single cell type, more than $90 \%$ of tracheid, resulting in some special properties, such as the simple wood texture, and lightly color, lower density, which limits it to be applied for interior decoration or wall panels. This work aims to develop a feasible method for fabricating densified Abies wood via the co-processing of chemical pretreatment, hot-pressing and post mechanical fixation. The color, chemical composition and physical/mechanical properties of the wood after and before densification were evaluated.

\section{Materials and methods Wood material and densified treatment}

Abies spp. wood was cut into blocks with a size of $80 \mathrm{~mm} \times 50 \mathrm{~mm}$ (longitudinal $\times$ tangential), which had three different thicknesses (in the radial direction) of $17.75,8.25$ and $3.15 \mathrm{~mm}$. The initial average moisture content of wood was $8.76 \%$. After the densified treatment, the average thicknesses of the thicker, medium and thinner samples were 3.25, 1.67 and $0.81 \mathrm{~mm}$, respectively. Densified wood was fabricated by combining chemical pretreatment and hot-pressing technology. First, equivalent volumes of $2.5 \mathrm{~mol} \mathrm{~L}^{-1} \mathrm{NaOH}$ and 0.4 mol L ${ }^{-1} \mathrm{Na}_{2} \mathrm{SO}_{3}$ aqueous solution were mixed, which is widely used in the chemical pulping industry. Wood samples were immersed into the prepared mixed solution and heated at $95^{\circ} \mathrm{C}$ for $5 \mathrm{~h}$ in a water bath. After the wood sank into the solution and the color was darkened, the chemical pre-treated wood was washed successively with $1 \% \mathrm{HCl}$ and deionized water and kept in water. The secondary step was hot-pressing with a press of DSKE (Wabash, USA) at $25 \mathrm{MPa}, 160^{\circ} \mathrm{C}$ for $12 \mathrm{~h}$ followed by covering wood surface with tinfoil and interrupted heating and hold the pressure for $24 \mathrm{~h}$. All the densified wood samples were dried at $80{ }^{\circ} \mathrm{C}$ for $24 \mathrm{~h}$ and stored for the following characterization. There were five replicates for each wood thickness.

\section{Test of chromaticity value}

The chromameter CR-5 (Konica Minolta, INC, Japan) was employed for chromaticity value test of wood surface during the densification treatment. The wood tangential section was measured using the chromameter under optional target mask (3 mm diameter) and the D65 light source (Daylight, color temperature of $6504 \mathrm{~K})$. The measurement type was reflectance mode at $10^{\circ}$ observer angle and specular component was excluded. Color measurements were completed at nine locations on each sample and mean values were calculated for each wood sample. The color was described using the CIEL* $a^{*} b^{*}$ system, which was established by International Commission on Illumination in 1976 . The CIE $L^{*} a^{*} b^{*}$ system consists of three perpendicular axes, where $L^{*}$ describes the lightness, $a^{*}$ the chromatic coordinates on the green to red axis and $b^{*}$ the chromatic coordinates on the blue to yellow axis. Five replicates in each wood thickness were completed. 


\section{SEM and FTIR}

The scanning electron microscopy (SEM, Quanta200, FEI, USA) was employed to observe the microstructure on the transverse section and tangential section of the densified wood. Before SEM observation, control wood and chemical-treated wood samples were ovendried until the constant weight was obtained and covered by gold sputtering. The observation condition was under vacuum and at an accelerating voltage of $25 \mathrm{kV}$. Fracture behavior of pristine wood and densified wood was observed after destruction in mechanical testing on Quanta200 at the same condition. The Fourier transform infrared spectrum of wood surface was collected using Nicolet 6700 (Thermo Scientific, USA) equipped with Smart orbit using attenuated total reflectance (ATR) model. Every sample was scanned between 400 and $4000 \mathrm{~cm}^{-1}$ at a resolution of $4 \mathrm{~cm}^{-1}$. To quantitatively compare the spectra of differently densified wood with the spectra of pristine wood for evaluating the chemical changes, the average spectra were further normalized based on the high band at nearly $1027 \mathrm{~cm}^{-1}$, assigned to $\mathrm{C}-\mathrm{O}$ stretching, even this band does not remain invariable throughout the whole experiments, because both lignin and carbohydrate exhibit this band [22, 23].

\section{Determination of physical properties}

The oven-dry density of all samples was calculated by "drymass/dry-volume". The compression ratio (CR) was calculated as follows:

$$
\begin{aligned}
& \text { (thickness Before treated }- \text { thickness } \text { After treated }) / \\
& \text { thickness Before treated } \times 100 \text {. }
\end{aligned}
$$

The loss weight ratio was calculated by:

$$
\begin{aligned}
& \left(\text { dry mass }{ }_{\text {Before treated }}-\right.\text { dry mass } \\
& \text { dry master treated } \\
& \text { Before treated }
\end{aligned}
$$

The lengths of all test samples were around $78.5 \mathrm{~mm}$. The densified wood and pristine wood samples were cut into approximately $12.0 \mathrm{~mm}$ in width. The modulus of rupture (MOR) and modulus of elasticity (MOE) were tested using the mechanical testing machine (UTM4304,Suns, Shenzhen, China). Three-point bending model was performed and the transverse loading was carried on the tangential surface of wood at the middle span of the test samples. The span of the test set was $56.0 \mathrm{~mm}$ and the loading rate was $5 \mathrm{~N} \mathrm{~min}{ }^{-1}$. After the mechanical testing, the final average moisture contents of pristine wood, thick densified wood, medium densified wood and thin densified wood were $8.58,7.38,8.29$ and $7.68 \%$, respectively. All mechanical data were calculated by builtin software MaterialTest 4.0. Excel (Microsoft, USA) and Origin 8.0 were employed to analyze data and plot figures.

\section{Results and discussion Color of densified wood}

Three different thicknesses of Abies wood (Fig. 1a) were selected for fabricating densified wood by the radial compression loading mode. The wood appearance and color were changed under the synergy of chemical pretreatment and hot-pressing (Fig. 1). In Fig. 1b, it can be found that the wood was squashed and its color
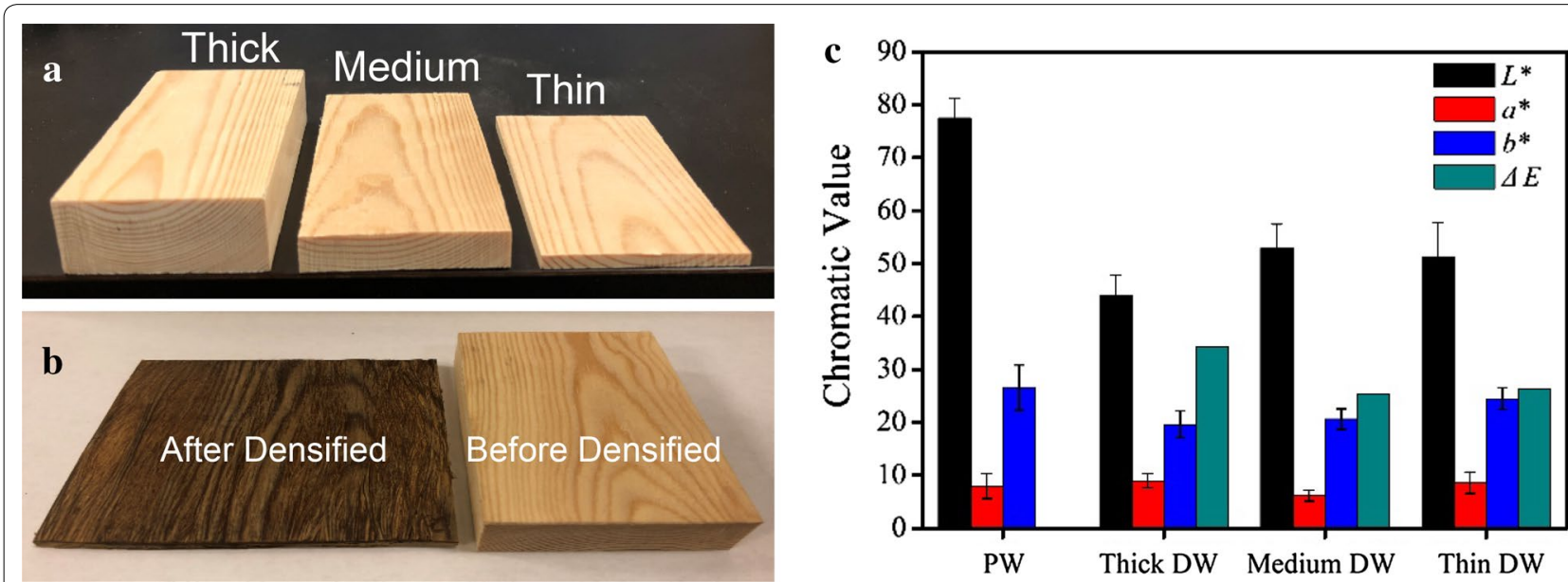

Fig. 1 Appearance and color changes of pristine wood (PW) and densified wood. a Three pristine wood samples with different thicknesses; $\mathbf{b}$ densified wood; c chromatic value of pristine wood and densified wood. DW densified wood 
darkened after the densification. On the densified wood surface, the light and black color alternation was caused by early wood and late wood, which was resulted from differences in the amount and size of wood cell walls. The extraction of sodium hydroxide solution from wood matrix resulted in the color changes after the densification. Previous studies reported that the $\mathrm{NaOH} / \mathrm{Na}_{2} \mathrm{SO}_{3}$ solution system can dissolve the extractives in wood and can also degrade hemicellulose and lignin in wood cell walls [15]. The degradation of hemicellulose and lignin was another reason for wood color changes in the densified wood [24].

Due to the polysaccharide composition of hemicellulose, various saccharic acids are gradually generated through the peeling reaction started from the reducing terminal group of polysaccharides in alkaline environment. Moreover, new chromophoric group may be polymerized by various saccharic acids and extractions [25]. In addition, lignin was also subjected to dearylation and dealkylation reaction with both nucleophile $\mathrm{SO}_{3}{ }^{2-}$ and $\mathrm{OH}^{-}$ions in chemical pretreatment and also produced some new chromophoric groups, such as quinone, epoxide, or lignosulphonates. Another reason for the color changes in wood densification was thermochromatism of the chemicals on wood surface. In this work, the $160{ }^{\circ} \mathrm{C}$ hot-pressing temperature and aerobic condition affected the migration and oxidation of chromophoric and auxochrome groups. The different colors between early wood and late wood perhaps were caused by the more cell wall polymers for stronger reaction degree. Bekhta et al. also reported that the brightness decreased in the short-term thermo-mechanically densified veneer of various wood species [26]. These mentioned results suggested that the synergistic effect of chemical pretreatment, hot-pressing and post mechanical fixation was responsible for color darkening in the densified wood. From the appearance, the densification treatment significantly improved the decorative value of Abies wood.

To quantify the changes of wood color in the densification, chromaticity value on wood surface was measured by the chromameter CR-5. In Fig. 1c, more wood brightness value $\left(L^{*}\right)$ and $b^{*}$ value decreased in the densified wood than those in the pristine wood. Decreasing of $L^{*}$ means wood color darkening, which may be caused by the degradation of hemicellulose and movement of extractives. Kubovský et al. also reported that the decrease of $L^{*}$ value in wood surface was closely related to the degradation of hemicellulose [24]. The decreasing of $b^{*}$ value describes the trend of the wood surface towards bluish, which can be explained by the reduction of a tonality component in color and a slight decreasing value of color saturation [26]. However, the slightly increased $a^{*}$ value in the densified wood indicated that the trend of wood surface became reddish. In conifer wood, it was shown directly proportional relationship between the extractive content and redness values [27]. This suggested that more extractives moved to the wood surface during the densification process. After comparing the colors of three different wood thicknesses, it was found that both $L^{*}$ and $b^{*}$ values of the thickest wood were lower than those in the wood samples with medium and thin thicknesses. With the increase of wood thickness, $b^{*}$ value trended toward to decrease. The value of $a^{*}$ showed no noticeable differences. The results suggested that the thickness of pristine wood affected its color after the densification treatment. This might be explained by the difference of chemical reaction efficiency with different wood thicknesses. More cell walls in the thickest wood meant more chemical reaction and generation of chromophoric groups, which would be shine through in the hot-pressing process. The total color difference $(\Delta E)$ was calculated based on the reference to pristine wood. The following formula was utilized:

$$
\Delta E=\left[\left(L_{x}-L_{0}\right)^{2}+\left(a_{x}-a_{0}\right)^{2}+\left(b_{x}-b_{0}\right)^{2}\right]^{1 / 2},
$$

where $L_{x}, a_{x}$ and $b_{x}$ are values measured in the densified wood and $L_{0}, a_{0}$ and $b_{0}$ are values measured in the pristine wood. Figure 1c shows that all densified wood presented significantly $\Delta E$, which can be easily visible with naked eyes. It was indicated that the densification in this work influenced wood color seriously.

\section{FTIR analysis}

To uncover the changes of wood cell wall polymers during the densification process, the infrared spectra were

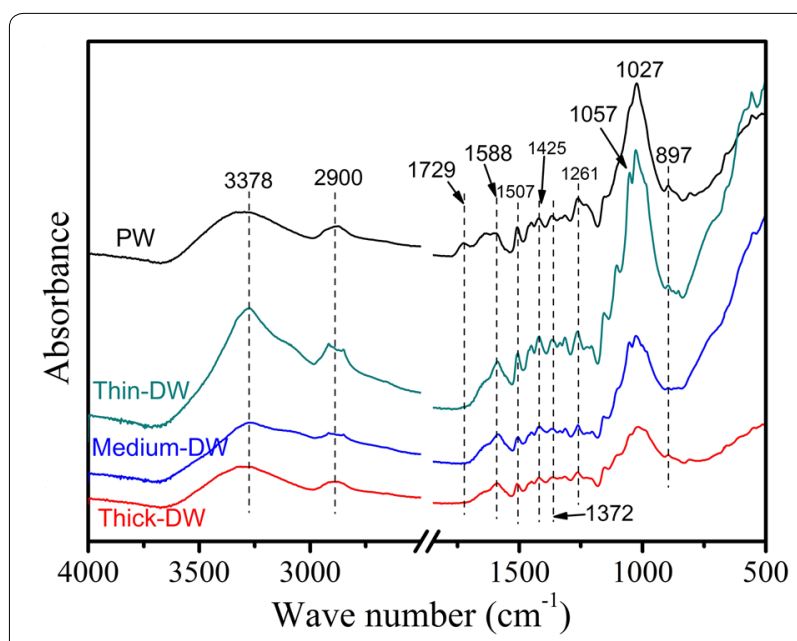

Fig. 2 Original infrared spectrum of pristine wood (PW) and densified wood (DW) 
collected and are shown in Fig. 2. The attribution of absorption band was according to the previous publish of Pandey [28]. The bands at $3378 \mathrm{~cm}^{-1}$ and $2900 \mathrm{~cm}^{-1}$ attributed to $\mathrm{O}-\mathrm{H}$ and $\mathrm{C}-\mathrm{H}$ stretching vibration in cellulose, hemicellulose and lignin. Some characteristic bands were analyzed in untreated wood and densified wood. The absorption band at $1729 \mathrm{~cm}^{-1}$ attributed to $\mathrm{C}=\mathrm{O}$ stretching vibration in unconjugated ketones, which was a characteristic band of hemicellulose [25, 28]. Disappearance of this band in the densified wood was caused by the deacetylation in hemicellulose, indicating that hemicellulose entirely dissolved in $\mathrm{NaOH}$ / $\mathrm{Na}_{2} \mathrm{SO}_{3}$ solution. After the densification treatment, the intensity ratio of $I_{1372} / I_{1507}$ decreased, which suggested that the content of holocellulose reduced and also proved the decrease in relative content of hemicellulose [29]. The band in range of $1588-1650 \mathrm{~cm}^{-1}$ appeared shoulder absorption peak in the pristine wood but turned into sharp peak only at $1588 \mathrm{~cm}^{-1}$ $(\mathrm{C}=\mathrm{C}$ stretching vibration on benzene ring) in the densified wood spectrum. It was indicated that the polar functional groups conjugated with benzene ring causing some changes. Because of the highly susceptible to nucleophilic reactions between carbonyl $\mathrm{C}=\mathrm{O}$ in lignin and hemicellulose and $\mathrm{SO}_{3}{ }^{2-}$ and $\mathrm{OH}^{-}$ions in $\mathrm{NaOH} /$ $\mathrm{Na}_{2} \mathrm{SO}_{3}$ solution, the disappearance of absorption band at $1650 \mathrm{~cm}^{-1}$ was related to the vanishing of conjugate carbonyl group attached to benzene ring. The sharp band at $1507 \mathrm{~cm}^{-1}$ was attributed to vibration absorption of benzene ring skeletal. In Fig. 2, this band was still present in the densified wood suggesting that there was no chemical reaction of benzene ring in $\mathrm{NaOH}$ / $\mathrm{Na}_{2} \mathrm{SO}_{3}$ solution. A certain amount of lignin in wood cell walls benefited to bonding strength in microfibrils. After normalization, the intensity of absorption band at $1507 \mathrm{~cm}^{-1}$ increased more in the densified wood than the pristine wood, indicating the increase of lignin relative content. It was also confirmed by the increased intensity ratio of $I_{1507} / I_{1372}$ (Table 1 ). To the contrary, previously studies insisted on lignin would be degraded in $\mathrm{NaOH} / \mathrm{Na}_{2} \mathrm{SO}_{3}$ solution $[18,30]$. This contradictory can be explained by the migration of degraded products of hemicellulose and lignin and depositing on the surfaces of the densified wood. The FTIR data collected on the densified wood surfaces by ATR mode in this study confirmed this finding as well. In addition, the lignin molecular structure may be changed from vitreous to high-elastic [1] and the changes of band at $1261 \mathrm{~cm}^{-1}$ (C-H of guaiacyl ring in lignin) indicated that lignin unit may be changed. The bands $1425 \mathrm{~cm}^{-1}$ $\left(\mathrm{C}-\mathrm{H}_{2}\right.$ scissoring vibration), $1372 \mathrm{~cm}^{-1}(\mathrm{C}-\mathrm{H}$ bending vibration) and $897 \mathrm{~cm}^{-1}\left(\mathrm{C}_{1}\right.$ vibration) can characterize cellulose and hemicellulose. And previous reports stated that the relative crystallinity of cellulose can be characterized by the band intensity ratio $I_{1372} / I_{2900}$ and $I_{1427} / I_{897}[31,32]$ and it was shown that this ratio was higher in the densified wood than the pristine wood. It can be inferred that the degradation of hemicellulose and partly amorphous cellulose resulted in the recombination of cellulose microstructure and finally caused the increase in cellulose crystallinity. Comparatively, the wood thickness might influence wood chemical properties to some extent. The probable reasons which affected the FTIR results were (1) the more massive thick specimens had greater potential for migrating and accumulating some chromatic extractives at the surface than thin specimens and (2) the inside moisture in the thin wood sample was more easily volatilized than the thicker wood in the hot-processing treatment.

\section{Physical and mechanical characterization}

Figure 3 shows the oven-dried densities, compression ratios (CR), MOE and MOR of the wood before and after densification. The wood oven-dry density increased over $1.00 \mathrm{~g} \mathrm{~cm}^{-1}$ in all densified woods compared to $0.455 \mathrm{~g} \mathrm{~cm}^{-1}$ of the pristine wood (Fig. 3a). The increment of density depended on wood sample thickness and the highest density was $1.227 \mathrm{~g} \mathrm{~cm}^{-1}(169 \%$ higher than the pristine wood) in the thickest wood sample. Moreover, wood density increased from the thin to the thick densified wood sample and CR showed the similar trend. The higher density appeared in the thicker wood sample, and the higher compressibility was obtained. Whereas, the lower density appeared in the thinner wood sample and the lower compressibility was achieved. As well known, many studies investigated various compression

Table 1 The band intensity and ratio of pristine wood (PW) and densified wood (DW)

\begin{tabular}{lllllll}
\hline & $\boldsymbol{I}_{\mathbf{1 3 7 2}} / \boldsymbol{I}_{\mathbf{1 5 0 7}}$ & $\boldsymbol{I}_{\mathbf{1 5 0 7}} / \boldsymbol{I}_{\mathbf{1 3 7 2}}$ & $\boldsymbol{I}_{\mathbf{1 3 7 2}} / \boldsymbol{I}_{\mathbf{2 9 0 0}}$ & $\boldsymbol{I}_{\mathbf{1 4 2 7}} / \boldsymbol{I}_{\mathbf{8 9 7}}$ & $\boldsymbol{I}_{\mathbf{1 5 8 8}}$ & $\boldsymbol{I}_{\mathbf{1 5 0 7}}^{\mathbf{b}}$ \\
\hline PW & 0.40 & 2.47 & 0.32 & 1.11 & - & 0.16 \\
Thin DW & 0.39 & 2.57 & 0.43 & 4.63 & 0.39 & 0.29 \\
Medium DW & 0.32 & 3.21 & 0.49 & 5.50 & 0.81 & 0.39 \\
Thick DW & 0.33 & 3.00 & 0.37 & 3.50 & 0.45 & 0.33 \\
\hline
\end{tabular}

$\mathrm{a}$ and $\mathrm{b}$ values indicate the intensity ratio of the absorption band and the maximum absorption band near $1027 \mathrm{~cm}^{-1}$ in that curve 

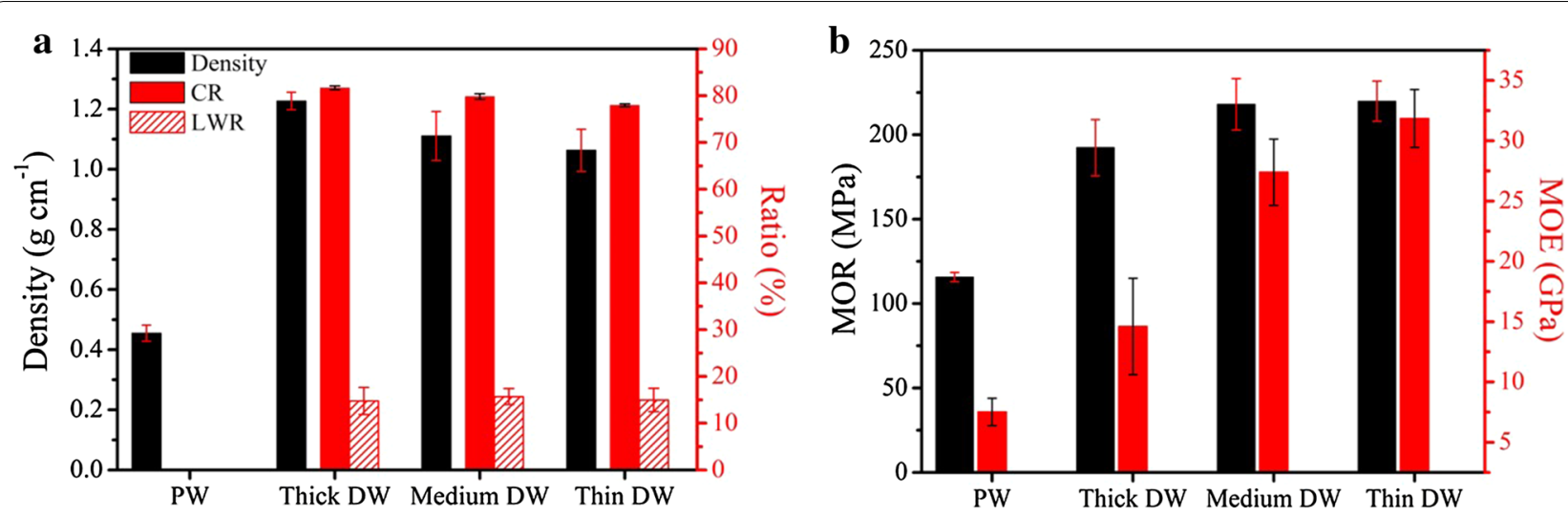

Fig. 3 Physical and mechanical characteristics of pristine wood (PW) and densified wood (DW). CR compression ratio, LWR loss weight ratio, MOR modulus of rupture, MOE modulus of elasticity

ratios of densified wood under different processing conditions. It was reported that the compression ratio was generally lower than $30 \%$ after the densification without any chemical pretreatment [33, 34]. However, in this work, the average compression ratio was approximately $80 \%$ in the radial direction of wood. We inferred that the pretreatment with $\mathrm{NaOH} / \mathrm{NaSO}_{3}$ solution was one of the reasons accounting for the higher compression ratio in densified wood. Also, the higher compaction ratio can be obtained by other pretreatments, such as saturated steam. Kutnar and Kamke treated Douglar-fir wood by pressurized steam before compression and obtained a compaction ratio of $153 \%$ using hydrothermal treatment with a pressure of lower than $5 \mathrm{MPa}$ [35]. According to the previous reports, part removal or degradation of amorphous polymers in wood is beneficial to adequate compression [36, 37]. In this work, wood hemicellulose and partly lignin were degraded in the pretreatment with $\mathrm{NaOH} / \mathrm{NaSO}_{3}$ solution, which was confirmed by FTIR results, and allowed the wood easier to be compressed in the hot-processing treatment. Meanwhile, the much higher density and strength of the wood could be achieved under sufficient compressibility [38]. This probably mainly attributed to synergistic effect of degradation of hemicellulose and lignin in the chemical pretreatment and recombination of wood cells during the hot-pressing process. Abies wood is easily densified and cell recombined because of the swelling of cell wall in the alkaline medium environment of $\mathrm{NaOH} / \mathrm{Na}_{2} \mathrm{SO}_{3}$ solution. From the similar loss weight ratio (about 15\%) in the densified wood, it was inferred that the wood samples with three different thicknesses subjected same degradation degrees.

The MOR and MOE in the thickness direction of the densified wood and pristine wood are shown in Fig. 3b.
Compared to the pristine wood, both MOR and MOE were increased in the densified wood. The maximum MOR is about $228.5 \mathrm{MPa}$ in the thinnest densified wood and increased by $97 \%$ than the pristine wood. MOE also increased up to $33.55 \mathrm{GPa}$ in the thinnest densified wood and $346 \%$ of that in pristine wood. Overall, the increment of strength showed negatively relation with the wood sample thickness. Cruz et al. reported that the content of hemicellulose in the densified wood showed high negative correlation to MOE and MOR [8], while the positive correlation was shown compared to the density of wood. As well known, wood cell wall is mainly consisted of cellulose, hemicellulose and lignin, and the cellulose chain aggregates microfibrils and serves as skeleton as well as hemicellulose and lignin are crosslinked into microfibrils. These three polymers have different contributions to the mechanical properties of wood [39]. Hence, in this work, the synergistic effect of hemicellulose and lignin was degraded or partly degraded during the $\mathrm{NaOH} / \mathrm{Na}_{2} \mathrm{SO}_{3}$ pretreatment combined with recombination of wood cells in the hot-pressing process, resulting in the increase in density and significant increase in MOR and MOE for the densified wood.

\section{Microstructure of densified wood}

To testify the changes on microstructure of wood cell walls, SEM was used to observe the transverse and tangential surfaces of the wood samples before and after the densification. On the transverse surface, it was shown the honeycomb holes (tracheid lumen) on natural Abies wood tracheids, which were arranged radial-regularly (Fig. 4a). Wood tracheids showed as grooves were interval with uniserial wood rays on the tangential surface (Fig. 4b). As well known, Abies wood is one of the softwood and its typical regular cell arrangement provides 


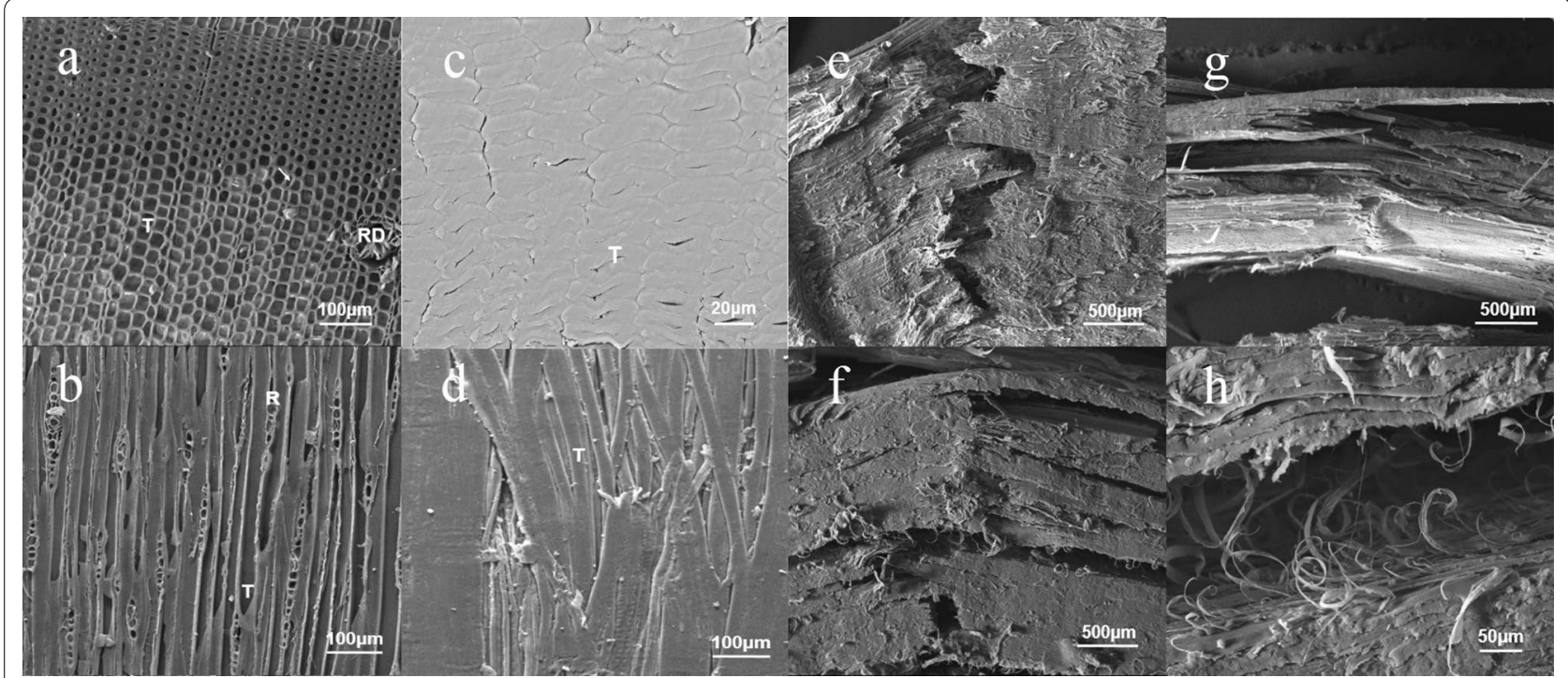

Fig. 4 SEM of pristine wood (a cross-section, b tangential section), densified wood (c cross-section, $\mathbf{d}$ tangential section), and rupture of various wood (e pristine wood, $\mathbf{f}$ thick densified wood, $\mathbf{g}$ thin densified wood, $\mathbf{h}$ magnifying of thick densified wood). $T$ tracheid, $R$ rays, $R D$ resin duct

excellent mechanical properties to make sure it can be widely used in wood structure building. However, the tracheid lumens on the transverse section of the densified wood almost vanished (Fig. 4c). Because of the regular radial arrangement, only cracks were present inside the compressed tracheids in the thickness direction. It was probably caused by the degradation of middle lamella at the loading direction during the hot-pressing. Meanwhile, previous reports suggested that such hydrothermal conditions generated more microcracks on wood cell walls $[25,40]$. Wood tracheids showed a bunch of aggregates on the tangential surface in the densified wood (Fig. 4d), which indicated that wood tracheids subjected to sufficient compression and recombination after the chemical, hot-pressing and mechanical co-processing. Furthermore, the fracture surfaces of the natural wood and densified wood were also observed by SEM (Fig. 4e-h). The three-point bending method and loading on the thickness direction of wood samples were used. In Fig. 4e, the fracture interface of natural wood shows jagged irregularly fracture and tracheids were pulled out to each other (Fig. 4e). On the other hand, the densified wood showed layered fracture interface (Fig. 4f, g), which can be explained by the longitudinal sliding in tracheid aggregates. The main reason of this fracture behavior was the decreased adhesion between tracheids after the degradation of hemicellulose and lignin in middle lamella. Although layered fractures occurred in all the densified wood samples, it was not obvious in the thinnest sample (Fig. 4g). A number of fibers present in fracture surface of the thick densified wood (Fig. 4h) further confirmed the degradation of intercellular layers and secondary cell walls of tracheid. Another reason should be considered was the lateral expansion of different wood thicknesses in the hot-processing treatment. When all specimens were compressed with the same compression stress, the thin specimens had more lateral restraint than the thick specimens due to the friction of the press plates [41]. At last but not least, because of the complicated wood structure, the thicker specimens were more likely to experience the fracture and stress concentration during compression, which may destroy wood structure easily and finally reduced MOR and MOE. There is sn evidence of fracture between tracheids in Fig. 4d, f. The tracheids are clearly displaced out of longitudinal alignment as a result of the Poisson effect.

\section{Conclusions}

In summary, the densified wood samples with three different thicknesses were fabricated by the combination of chemical pretreatment, hot-pressing and post mechanical treatments. Surface color of Abies wood changed obviously after the densification. Quantitative results indicated that the values of brightness $L^{*}$ and $b^{*}$ decreased but the value of $a^{*}$ showed a slight increase in the densified wood. The FTIR examinations confirmed that the color changes can be explained by the degradation of hemicellulose and lignin in wood cell walls and migration of extractives during the densification process. New chromophoric groups generated from re-polymerization of wood cell wall degradation product were the other reason for the color changes in the densified 
wood. In this work, sufficient removal of wood polymers resulted in the average compression ratio of about $80 \%$ in the radial direction of the pristine wood. Furthermore, the increased compression ratio positively related to the wood density. The density of wood increased with wood thickness up to $1.227 \mathrm{~g} \mathrm{~cm}^{-1}$, counting $169 \%$ higher than the pristine wood. Being benefited from the increased density, MOR and MOE in the thickness direction of the densified wood also markedly enhanced. The fracture interface of the densified wood reconfirmed the degradation of polymers in wood cell walls. Moreover, the thickness of initial wood sample affected the color, density, chemical groups and mechanical properties in the densified wood. All the mentioned results suggested that the densified softwood can be easily fabricated using the proposed method and the new densified softwood can be considered as an interior decoration material.

\section{Abbreviations}

CR: compression ratio; DW: densified wood; FTIR: Fourier transform infrared spectrum; MOE: modulus of elasticity; MOR: modulus of rupture; PW: pristine wood; SEM: scanning electron microscopy.

\section{Acknowledgements}

The authors acknowledge the Advanced Analysis\&Testing Center of Nanjing Forestry University.

\section{Authors' contributions}

JS designed the experiments and wrote the manuscripts. JP and JS performed the experiments and discussed the results. QH, LC and SS revised the manuscript and provided some valuable advices. All authors read and approved the final manuscript.

\section{Funding}

The authors like to thanks for finical supporting of the National Key Research \& Development Program of China (2017YFD0600204).

\section{Availability of data and materials}

Not applicable.

\section{Competing interests}

The authors declare that they have no competing interests.

\section{Author details}

${ }^{1}$ College of Materials Science and Engineering, Nanjing Forestry University, Nanjing 210037, China. ${ }^{2}$ Yihua Lifestyle Technology Co., Ltd, Huaidong Industrial Zone, Lianxia Town, Chenghai District, Shantou 515834, China. ${ }^{3}$ Department of Mechanical and Energy Engineering, University of North Texas, Denton, TX 76203, USA.

Received: 10 July 2019 Accepted: 16 January 2020

Published online: 30 January 2020

\section{References}

1. Navi P, Heger F (2004) Combined densification and thermos-hydromechanical processing of wood. MRS Bull 29(5):332-336

2. Kamke FA, Sizemore H (2008) Viscoelastic thermal compression of wood. US Patent No. US7404422B2

3. Kariz M, Kuzman MK, Sernek M, Hughes M, Rautkari L, Kamke FA, Kutnar A (2017) Influence of temperature of thermal treatment on surface densification of spruce. Eur J Wood Prod 75:113-123
4. Wehsener J, Brischke C, Meyer-Veltrup L, Hartig J, Haller P (2018) Physical, mechanical and biological properties of thermos-mechanically densified and thermally modified timber using the $\mathrm{Vacu}^{3}$-process. Eur J Wood Prod 76:809-821

5. Pertuzzatti A, Missio AL, de Cademartori PHG, Santini EJ, Haselein CR, Berger C, Gatto DA, Tondi G (2018) Effect of process parameters in the thermomechanical densification of Pinus elliottii and Eucalyptus grandis fast-growing wood. BioRes 13(1):1576-1590

6. Liu H, Shang J, Chen X, Kamke FA, Guo K (2014) The influence of thermal-hydro-mechanical processing on chemical characterization of Tsuga heterophylla. Wood Sci Technol 48:373-392

7. Bao M, Huang X, Jiang M, Yu W, Yu Y (2017) Effect of thermos-hydromechanical densification on microstructure and properties of poplar wood (Populus tomentosa). J Wood Sci 63:591-605

8. Cruz N, Bustos C, Aguayo MG, Cloutier A, Castillo R (2018) Impact of the chemical composition of Pinus radiata wood on its physical and mechanical properties following thermo-hygromechanical densification. BioRes 13(2):2268-2282

9. Guo J, Song L, Salmén L, Yin Y (2015) Changes of wood cell walls in response to hygro-mechanical steam treatment. Carbohyd Polym 115:207-214

10. Yin J, Yuan T, Lu Y, Song K, Li H, Zhao G, Yin Y (2017) Effect of compression combined with steam treatment on the porosity, chemical composition and cellulose crystalline structure of wood cell walls. Carbohyd Polym 155:163-172

11. Dömény J, Čermák P, Koiš V, Tippner J, Rousek R (2018) Density profile and microstructural analysis of densified beech wood (Fagus sylvatica L.) plasticized by microwave treatment. Eur J Wood Prod 76:105-111

12. Yu Y, Zhang F, Zhu S, Li H (2017) Effects of high-pressure treatment on Poplar wood: density profile, mechanical properties, strength potential index, and microstructure. BioRes 12(3):6283-6297

13. Li H, Zhang F, Ramaswamy HS, Zhu S, Yu Y (2016) High-pressure treatment of Chinese fir wood: effect on density, mechanical properties, humidity-related moisture migration, dimensional stability. BioRes 11(4):10497-10510

14. Gong M, Lamason C, Li L (2010) Interactive effect of surface densification and post-heat-treatment on aspen wood. J Mater Process Technol 210:293-296

15. Neyses B, Rautkari L, Yamamoto A, Sandberg D (2017) Pre-treatment with sodium silicate, sodium hydroxide, ionic liquids or methacrylate resin to reduce the set-recovery and increase the hardness of surfacedensified Scots pine. iForest 10:857-864

16. Berzins GV, Rocens K (1970) Strength and elasticity of the ammonia treated and compressed birch wood. Holztechnologie 11:48-52

17. Pařil $P$, Brabec M, Maňák $O$, Rousek $R$, Rademacher $P$, Čermák $P$, Dejmal A (2014) Comprarion of selected physical and mechanical properties of densified beech wood plasticized by ammonia and saturated steam. Eur J Wood Prod 72:583-591

18. Song J, Chen C, Zhu S, Zhu M, Dai J, Ray U, Li Y, Kuang Y, Li Y, Quispe N, Yao Y, Gong A, Leiste UH, Bruck HA, Zhu JY, Vellore A, Li H, Minus ML, Jia Z, Martini A, Li T, Hu L (2018) Processing bulk natural wood into a highperformance structural material. Nature 554:224-228

19. Zhu M, Song J, Li T, Gong A, Wang Y, Dai J, Yao Y, Luo W, Henderson D, Hu L (2016) Highly anisotropic, highly transparent wood composites. Adv Mater 28:5181-5187

20. Song J, Chen C, Wang C, Kuang Y, Li Y, Jiang F, Li Y, Hitz E, Zhang Y, Liu B, Gong A, Bian H, Zhu J, Zhang J, Li J, Hu L (2017) Superflexible wood. ACS Appl Mater Interfaces 9:23520-23527

21. Wang X, Zhan T, Liu Y, Shi J, Pan B, Zhang Y, Cai L, Shi SQ (2018) Large-size transparent wood for energy-saving building applications. Chemsuschem 11(23):4086-4093

22. Rosu D, Teaca CA, Bodirlaru R, Rosu L (2010) FTIR and color change of the modified wood as a result of artificial light irradiation. J Photochem Photobiol B Bool. 99:144-149

23. Timar MC, Varodi AM, Gurău L (2016) Comparative study of photodegradation of six wood species after short-time UV exposure. Wood Sci Technol 50:135-163

24. Kubovský I, Kačík F, Vel'ková V (2018) The effects of $\mathrm{CO}_{2}$ laser irradiation on color and major chemical component changes in hardwoods. BioRes. 13(2):2515-2529 
25. Shi J, Lu Y, Zhang Y, Cai L, Shi SQ (2018) Effect of thermal treatment with water, $\mathrm{H}_{2} \mathrm{SO}_{4}$ and $\mathrm{NaOH}$ aqueous solution on color, cell wall and chemical structure of poplar wood. Sci Rep 8:17735

26. Bekhta P, Proszyk S, KrystofiakT (2014) Colour in short-term thermosmechanically densified veneer of various wood species. Eur J Wood Prod 72:785-797

27. Gierlinger $N$, Jacques $D$, Grabner M, Wimmer R, Schwanninger M, Rozenberg P, Paques LE (2004) Colour of larch heartwood and relationships to extractives and brown-rot decay resistance. Trees 18(1):102-108

28. Pandey KK (1999) A study of chemical structure of soft and hardwood and wood polymers by FTIR spectroscopy. J Appl Polymer Sci 71:1969-1975

29. Li G, Huang A, Qin T, Huang L (2010) FTIR studies of masson pine wood decayed by brown-rot fungi. Spectrosc Spect Anal 30(8):2133-2136 Chinese, English Abstract

30. Frey M, Widner D, Segmehl JS, Casdorff K, Keplinger T, Burgert I (2018) Delignified and densified cellulose bulk materials with excellent tensile properties for sustainable engineering. ACS Appl Mater Interfaces 10:5030-5037

31. Nelson ML, O'Connor RT (1964) Relation of certain infrared bands to cellulose crystallinity and crystal lattice type. Part II. A new infrared ratio for estimation of crystallinity in celluloses I and II. J Appl Polym Sci 8:1325-1341

32. Åkerholm M, Hinterstoisser B, Salmén L (2004) Characterization of the crystalline structure of cellulose using static and dynamic FT-IR spectroscopy. Carbohyd Res 339(3):569-578

33. Laine K, Rautkari L, Hughes M (2013) The effect of process parameters on the hardness of surface densified Scots pine solid wood. Eur J Wood Prod 71:13-16

34. Laskowska A (2017) The influence of process parameters on the density profile and hardness of surface-densified Birch wood (Betula pendula Roth). BioRes 12(3):6011-6023
35. Kutnar A, Kamke FA (2013) Transverse compression behavior of Douglasfir (Pseudotsuga menziesii) in saturated steam environment. Eur J Wood Prod 71:443-449

36. Yano H, Hirose A, Clark N, Collins P, Yazaki Y (2001) Effects of high temperature and high pressure alkaline pretreatments for the production of high strength resin-impregnated compressed wood. Moluzai Gakkaishi 47(4):337-343 (In Japanese)

37. Shams MI, Yano H (2009) Development of selectively densified surface laminated wood based composites. Eur J Wood Prod 67:169-172

38. Zhan J, Avramidis S (2017) Transversal mechanical properties of surfacedensified and hydrothermally modified needle fir wood. Wood Sci Technol 51:721-738

39. Wagner L, Bader TK, Ters T, Fackler K, Borst KD (2015) A combined view on composition, molecular structure, and micromechanics of fungal degraded softwood. Holzforschung 69(4):471-482

40. Wang X, Zhao L, Xu B, Li Y, Wang S, Deng Y (2018) Effects of accelerated aging treatment on the microstructure and mechanics of wood-resin interphase. Holzforschung 72(3):235-241

41. Wolcott MP, Kasal B, Kamke FA, Dillard DA (1989) Testing small wood specimens in transverse compression. Wood Fiber Sci 21(3):320-329

\section{Publisher's Note}

Springer Nature remains neutral with regard to jurisdictional claims in published maps and institutional affiliations.

\section{Submit your manuscript to a SpringerOpen ${ }^{\circ}$ journal and benefit from:}

- Convenient online submission

- Rigorous peer review

- Open access: articles freely available online

- High visibility within the field

- Retaining the copyright to your article

Submit your next manuscript at springeropen.com 